\title{
Sistem Pemberian Pakan Ayam Otomatis Berbasis Loadcell
}

\author{
Nasrul Harun \\ Jurusan Teknik Elektro, Prodi Teknik Listrik, Politeknik Negeri Padang \\ e-mail: nasrul.harun1959@gmail.com
}

\begin{abstract}
ABSTRAK
Proses pemberian pakan ayam saat ini masih menggunakan tenaga manusia. Pada umumnya, masyarakat menggunakan tangan untuk memberi pakan ayam maka membutuhkan waktu yang lama. Saat ini, pemberian pakan ayam secara manual kurang maksimal dikarenakan makanan ayam yang diberikan tidak merata. Untuk mengurangi dan meminimalisir hal tersebut, maka perlu dibuatnya pemberi pakan ayam otomatis berdasarkan berat dari wadah pakan, berat wadah pakan yang telah terisi dideteksi oleh sensor Loadcell, sehingga makanan ayam yang telah habis dari wadah pakan akan tetap terisi secara otomatis karna wadah pakan akan selalu terisi sesuai dengan kebutuhan makan ayam. Sensor Loadcell sebagai input yang mendeteksi berat dari wadah pakan ayam yang berkurang, sesuai dengan pengaturan Loadcell pada program. Berat pada loadcell melebihi kapasitas yaitu 1000 g maka secara otomatis motor servo akan mentup pintu pada bak dan pakan tidak akan keluar lagi. Motor power window akan berhenti menggerakan bak kembali ke posisi semula. Pada pengujian pengaplikasian motor power window ini menggunakan relay untuk membalik putaran motor power window pada bak pakan dari CW dan CCW
\end{abstract}

Kata Kunci Arduino, Loadcell, motor power window, motor servo

\section{ABSTRACT}

The process of chicken feed is currently still using human labor. In general, people use their hands to feed chicken, so it takes a long time. At present, manual feeding of chickens is less than optimal because the chicken food provided is uneven. To reduce and minimize this, it is necessary to make an automatic chicken feeder based on the weight of the feed container, the weight of the filled feed container is detected by the Loadcell sensor, so that chicken food that has been exhausted from the feed container will remain filled automatically because the feed container will always filled in accordance with the needs of eating chicken. Loadcell sensor as input that detects the weight of a reduced chicken feed container, in accordance with the Loadcell settings in the program. Relay on this tool serves as a motor power window control. The power window motor in this tool functions as the output of the chicken feed container drive, if the load has been filled based on the detection by loadcell, the power window motor in this tool moves in CW (clock wise) and the servo motor moves in CCW (counter clock wise). Chicken feed tanks move automatically $C W$ and $C C W$ which are controlled by the power window motor and servo motor, the motor works based on weight detection by the Loadcell sensor.

Keyword: Arduino, Loadcell, power window motor, servo motor

(C) 2019 Elektron Jurnal Ilmiah

\section{I.PENDAHULUAN}

Peternakan ayam sekarang mulai disukai dan dilirik oleh sebagian masyarakat dan ikut menggalakan pemeliharaan ayam. Peternakan ayam juga menjanjikan penghasilan yang besar apabila ditekuni. Manajemen pemeliharaan yang meliputi kebersihan kandang dan strategi pemberian pakan adalah salah satu kunci keberhasilan ayam, pemberian pakan harus sesuai kandungan nutrisi yang lengkap dan cukup untuk ayam dengan berbagai tingkat umur. Karena pemeliharaan yang bagus dari kecil hingga dewasa sebagai penentu ayam itu bisa berproduksi dengan maksimal.[1]
Berdasarkan beberapa survey yang dilakukan, seorang peternak ayam diharuskan selalu standby untuk memberikan pakan. Untuk beternak dibutuhkan tenaga kerja dan waktu pemberian pakan secara teratur. Pada umumnya masyarakat masih banyak menggunakan tangan atau wadah untuk memberi pakan ayam maka membutuhkan waktu yang lama dan tenaga kerja yang banyak. Bila pemberian pakan ayam ini di rubah secara otomatis, maka pemberian pakan ayam lebih efektif dan efisien.[2]

Dengan demikian saat ini dibutuhkan suatu sistem yang dapat digunakan untuk mempermudah para peternak ayam untuk pemberian pakan otomatis 
merupakan solusi untuk mengatasi hal tersebut, karena dalam prosesnya sistem bekerja melakukan pemberi pakan ayam secara terarur.

\section{A. Diagram blok}

\section{METODE}

Diagram Blok suatu rangkaian merupakan salah satu bagian terpenting dalam perancangan suatu alat, karena dari blok diagram rangkaian inilah dapat diketahui cara kerja rangkaian secara keseluruhan. Sehingga keseluruhan block diagram tersebut akan menghasilkan suatu sistem yang dapat difungsikan sesuai dengan perancangan. Adapun block diagram dari sistem pemberian pakan ayam otomatis berbasis loadcell yaitu:

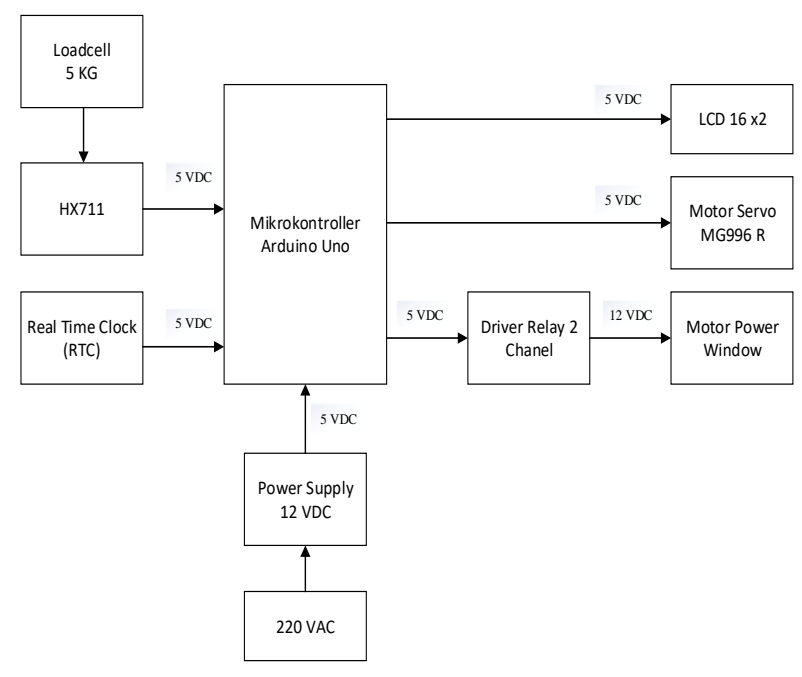

Gambar 1. Block Diagram Sistem

Dari blok diagram diatas dapat dijelaskan fungsi masing-masing blok sistem, sebagai berikut, Sensor loadcell berfungsi sebagai input, dimana sensor ini bekerja dengan pendeteksi berat pada wadah pakan. Modul HX711 berfungsi untuk menguatkan keluaran dari loadcell serta mengkonversikan data analog ke digital.RTC (Real Time Clock) berfungsi sebagai input waktu yang ditetapkan. Arduino berfungsi sebagai kontroler dari keseluruhan sisitem yang akan mengatur kinerja dari sistem pengatur alat. Power supply berfungsi sebagai supply pada alat ini, karena pada setiap rangkaian membutuhkan supply dalam bentuk tegangan dc. Relay berfungsi sebagai kendali motor power window untuk berputar $\mathrm{CW}$ ataupun CCW. Motor power window berfungsi sebagai penggerak pada bak. Motor servo MG996 R berfungsi sebagai pembuka dan penutup pintu pada bak. LCD berfungsi sebagai menampilkan data dari loadcell dan RTC (Real time clock)

\section{B. Perancangan Hardwere}

Perancangan hardware yaitu terdiri dari perancangan mekanik dan perancangan elektronik. Perancangan mekanik yaitu membuat perancangan untuk mekanik alat sistem pemberian pakan ayam otomatis serta perancangan elektronik yaitu membuat rangkaian elektronika yang akan direalisasikan ke bentuk Printed Circuit Board (PCB).

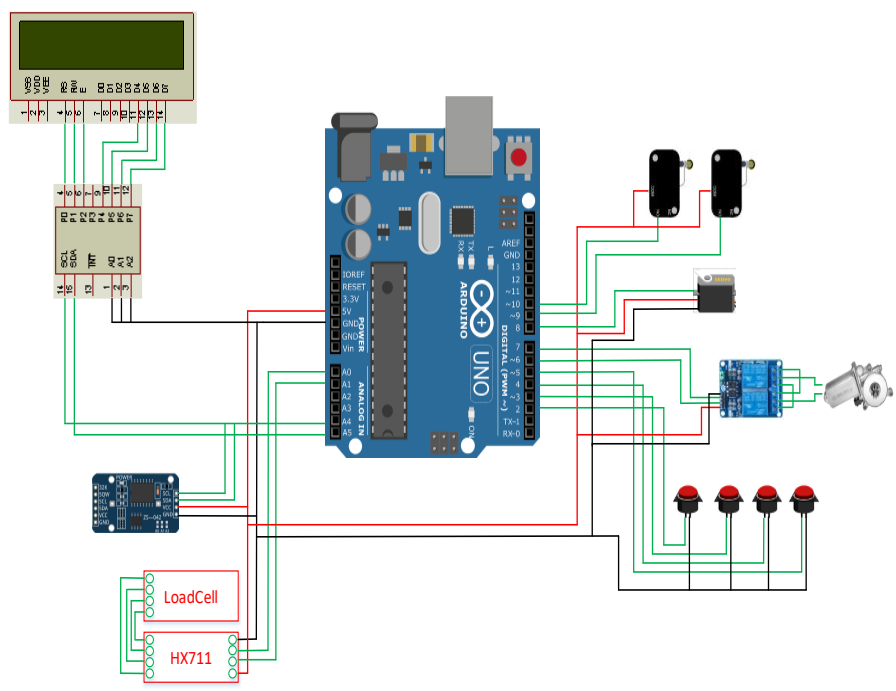

Gambar 2. Rangkaian Keseluruhan pada Arduino

Sensor Load Cell memiliki 4 kaki keluaran yang dihubungkan dengan modul HX-711 sebagai penguat keluaran data pembacaan dari load cell yang terdiri dari 4 pin yaitu VCC, DT, SCK dan GND. Pin DT dan SCK terhubung ke pin Analog Arduino Uno A0 dan A1 arduino. Untuk tegangan input yang terhubung pada VCC dan GND sensor, maka dibutuhkan tegangan sebesar $5 \mathrm{~V}_{\mathrm{DC}}$ sebagai tegangan inputnya. Sensor load cell ini digunakan untuk mengetahui berat wadah pakan ayam. Untuk rangkaian pin sensor load cell yang terhubung ke arduino.

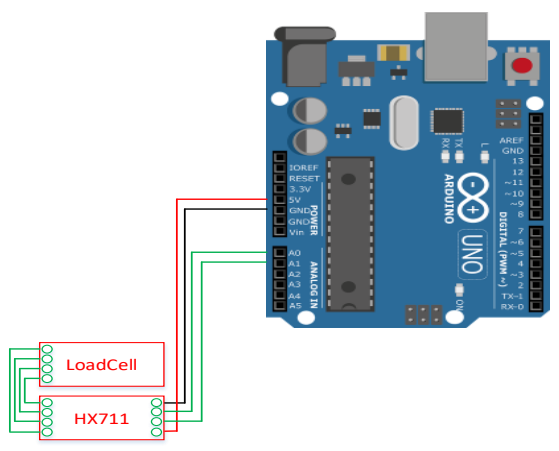

Gambar 3. Rangkaian Loadcell pada Arduino

Relay berfungsi sebagai saklar otomatis, dimana relay digunakan untuk mengatur motor power window. 
Relay yang digunakan menggunakan tegangan input sebesar 12 Vdc dari power supply dan data pengaturan relay aktif atau tidak aktif di kontrol menggunakan arduino uno.

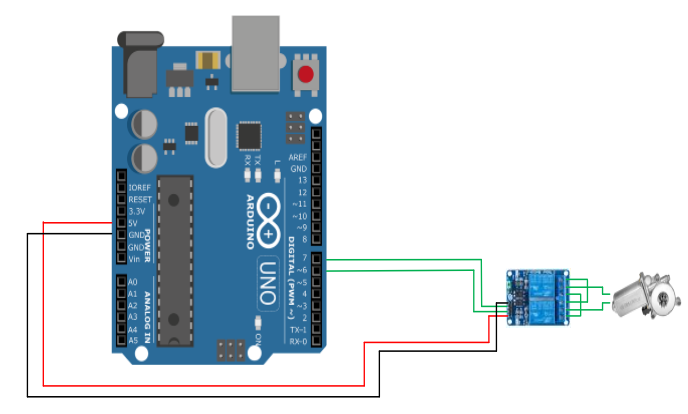

Gambar 4. Rangkaian Power window pada arduino

\section{Perancangan Softwere}

Perancangan software dimulai setelah pembuatan perangkat hardware dilakukan. Untuk penyusunan software yang mengendalikan peralatan tersebut, bahasa pemrograman yang digunakan pada tugas akhir ini adalah bahasa $\mathrm{C}$. Agar perancangan perangkat lunak dapat dipahami dan mudah dalam pembuatan, maka terlebih dahulu membuat sebuah diagram alir (flow chart) untuk menggambarkan jalannya program secara keseluruhan terhadap sistem. Flow Chart ini dirancang untuk sistem pemberian pakan ayam otomatis berbasis loadcell. Berdasarkan flowchart pada gambar 5 dapat dideskripsikan bahwa prinsip kerja dari alat ini adalah Sistem pemberian pakan ayam otomaris. Sistem ini menggunakan modul real time clock dan sensor loadcell, yang dimana modul real time clock berfungsi untuk mengatur waktu pakan ayam, untuk waktu pemberian pakan ini telah diatur untuk 2 kali sehari. Sensor loadcell berfungsi sebagai menentukan berat pada wadah pakan, jika pada wadah pakan sudah terbaca $1 \mathrm{~kg}$ maka akan mengirimkan data ke arduino. Untuk pemberian pakan otomatis ini dapat disetting secara manual, sesuai dengan waktu yang diinginkan.

Apabila waktu pemberian pakan burung ayam sudah di setting, maka motor power window bekerja dan motor servo akan membuka bak pakan. Apabila pakan ayam belum melebihi takaran berat $1 \mathrm{~kg}$ maka bak akan terus berjalan sebelum takaran pakan sudah melebihi $1 \mathrm{~kg}$. Pada alat ini menggunakan limit swicth untuk membalik putaran motor power window pada bak pakan dari kanan ke kiri. Jika pada wadah pakan sudah melebihi takaran $1 \mathrm{~kg}$ maka motor servo menutup bak pakan dan motor power window kembali posisi semula.

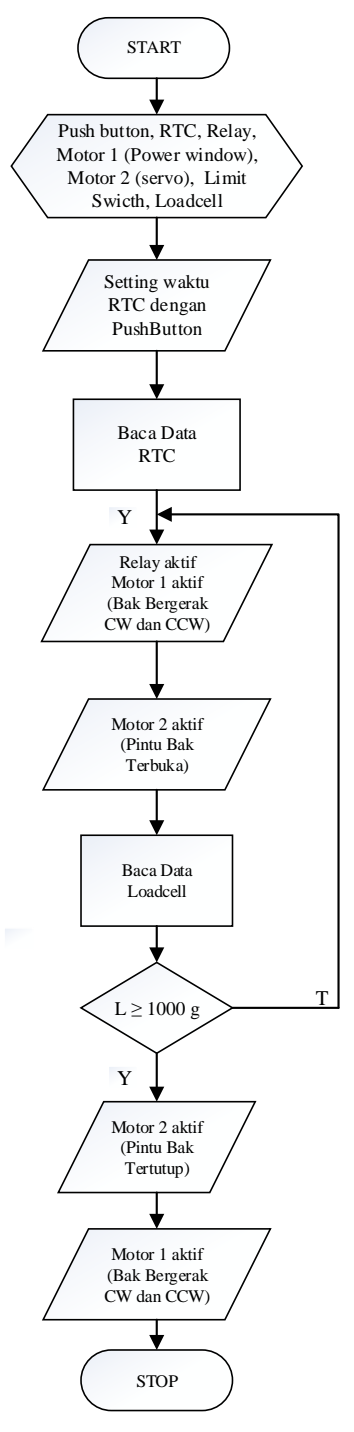

Gambar 5. Flowchart

Setelah pemberian pakan ayam yang pertama maka untuk pemberian pakan yang kedua sesuai dengan waktu yang telah disetting pada sebelumnya. Dan untuk sistem kerja dari pemberian pakan yang kedua sama seperti pemberian pakan ayam yang pertama.

\section{Perancangan Mekanik}

Perancangan mekanik merupakan proses penyelesaian akhir sehingga terwujudnya benda jadi. Pada perancangan mekanik ini meliputi merancang desain rancang bangun sistem pemberian pakan ayam otomatis , membuat kerangka kandang ,bak pakan, wadah pakan dan pembuatan untuk kedudukan loadcell . 

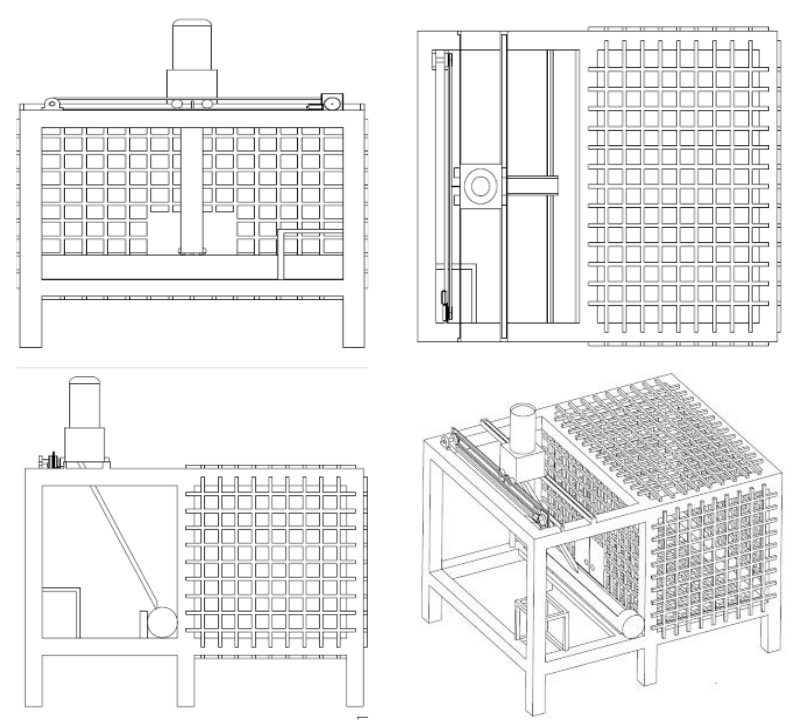

Gambar 6. Rancangan Mekanik Sistem

\section{III.HASIL DAN PEMBAHASAN}

\section{A. Pengujian Loadcell}

Pengujian load cell dilakukan dengan menggunakan timbangan dan pengukuran yang terbaca pada serial monitor arduino. Tujuan dari pengukuran ini adalah untuk mengetahui berat yang terbaca oleh sensor dengan berat yang sebenarnya. Pada load cell terdapat kabel yang berwarna merah dan hitam sebagai input tegangan load cell dan kabel yang bewarna hijau dan putih merupakan keluaran dari load cell yang akan dihubungkan ke rangkaian penguat. Pada kabel hijau dan putih dilakukan pengukuran untuk mengetahui tegangan output dari load cell.

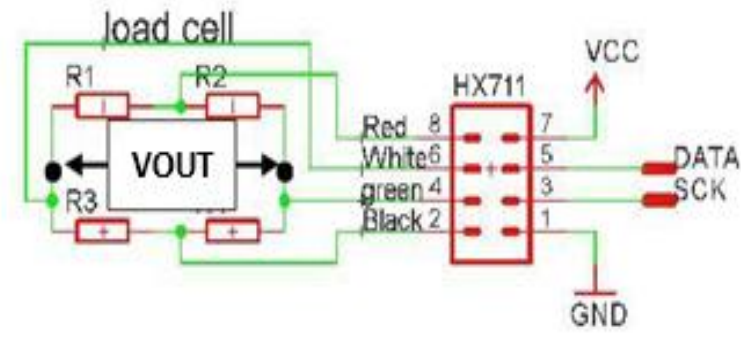

Gambar 7. Titik Pengukuran tegangan Loadcell

Pengujian terhadap sensor berat (loadcell) yang harus diperhatikan dengan teliti adalah pada keadaan awal (tanpa beban), keluaran dari load cell harus 0 volt yang berarti keadaan tersebut dalam keadaan simbang. Titik pengukuran tegangan pada load cell maka didapat hasil pengukuran. Berikut adalah tabel dari hasil pengukuran tegangan pada sensor load cell:
Tabel 1. Hasil pengukuran tegangan pada loadcell

\begin{tabular}{ccc}
\hline No. & Berat (gr) & $\begin{array}{c}\text { Tegangan } \\
\text { Vout }(\mathrm{mV})\end{array}$ \\
\hline 1. & $500 \mathrm{gr}$ & $2,4 \mathrm{mV}$ \\
\hline 2. & $1000 \mathrm{gr}$ & $2,6 \mathrm{mV}$ \\
\hline
\end{tabular}

Tabel 2. Hasil Pengukuran pada sistem pemberian pakan otomatis

\begin{tabular}{|c|c|c|c|c|c|c|c|c|c|c|c|}
\hline No & $\begin{array}{r}\text { Input } \\
\text { Pakan } \\
\text { Ayam }\end{array}$ & \multicolumn{6}{|c|}{ Hasil Penimbangan Pakan Ayam } & \multicolumn{6}{|c|}{ Pengujan timbangan Digital (gram) } \\
\cline { 3 - 12 } & 1 & $\mathbf{2}$ & $\mathbf{3}$ & $\mathbf{5}$ & $\mathbf{5}$ & $\mathbf{1}$ & $\mathbf{2}$ & $\mathbf{3}$ & 4 & $\mathbf{5}$ \\
\hline 1. & $500 \mathrm{~g}$ & 501 & 510 & 506 & 504 & 515 & 500.01 & 500.10 & 500.06 & 500.04 & 500.15 \\
\hline 2. & $1000 \mathrm{~g}$ & 1015 & 1025 & 1011 & 1020 & 1021 & 1001.5 & 1002.5 & 1001.1 & 1002.0 & 1002.1 \\
\hline
\end{tabular}

Dari hasil pengujian dan analisis keseluruhan menunjukkan perbedaan nilai yang tertera pada timbangan biasa dengan nilai pada alat. Nilai yang terdapat pada alat tidak tetap hal ini disebabkan adanya nilai toleransi, akan tetapi dari segi program alat ini sudah bekerja dengan baik.

Dari hasil pengukuran pada tabel 2 terdapat perbedaan hasil yang terukur oleh timbangan dengan berat yang sebenarnya, sehingga didapat persentase kesalahannya. Karena load cell telah dikalibrasi sebelumnya, sehingga pengukuran berat dari load cell dan timbangan sebenarnya hanya memiliki sedikit perbedaan pengukuran berat karena kesensitifan load cell. Dengan kesalahan yang sedikit tersebut, dapat dikatakan berat yang terbaca oleh load cell tidak jauh berbeda dengan berat yang diukur dengan timbangan sebenarnya (timbangan digital).

Untuk hasil pada serial monitor dan LCD dapat dilihat pada gambar 8 dan 9 berikut ini berikut:

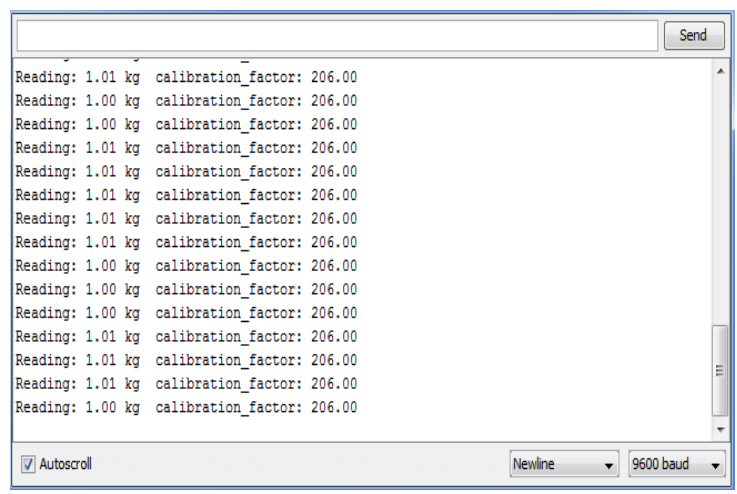

Gambar 8. Hasil pada serial monitor arduino 


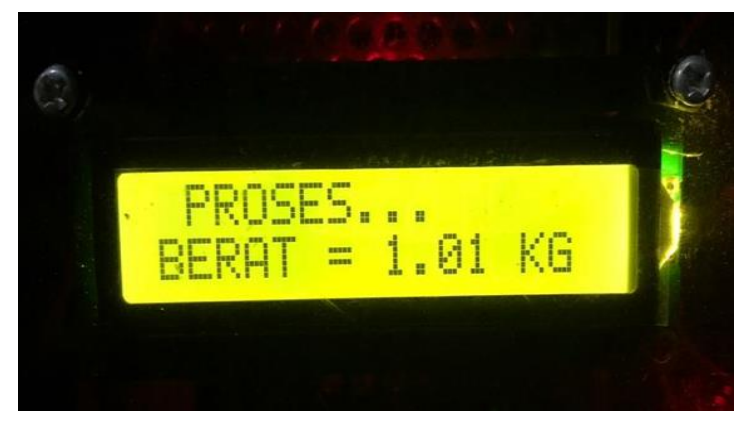

Gambar 9. Hasil pengukuran pada LCD

\section{B. Pengujian Motor Power Window}

Tujuan dilakukan pengukuran dan pengujian terhadap tegangan dan arus pada motor power window yaitu untuk mengetahui pengaruh arus yang terjadi pada saat diam dan bekerja. Pengukuran tegangan dan arus ini dilakukan pada motor yang semula diam sampai motor bergerak ketika waktu pada pemberian pakan sudah di setting. Yang dimana pada relay bekerja setelah menerima sinyal dari real time clock.

Berikut hasil pengukuran tegangan dan arus pada motor power window:
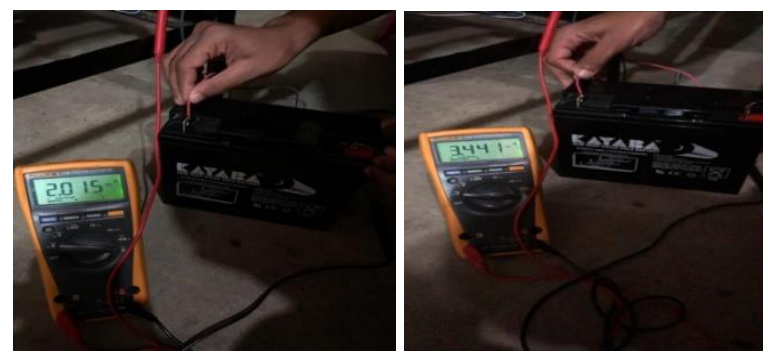

Gambar 10. Pengukuran tegangan power window

Tabel 3. Pengukuran tegangan dan arus pada motor power window

\begin{tabular}{cccc}
\hline No. & Pengukuran & $\begin{array}{c}\text { Tegangan } \\
\text { (Vout) }\end{array}$ & $\begin{array}{c}\text { Arus } \\
\text { (Ampere) }\end{array}$ \\
\hline 1. & Tanpa Beban & 12 VDC & $2,015 \mathrm{~A}$ \\
\hline 2. & Berbeban & 12 VDC & $3,441 \mathrm{~A}$ \\
\hline
\end{tabular}

Dalam melakukan perencanaan daya motor power window terlebih dahulu mengetahui daya output motor yang didapat dengan menggunakan perhitungan sebagai berikut:

$$
\mathrm{P}=\mathrm{V} \times \mathrm{I}
$$

Dimana :

$$
\begin{array}{ll}
\mathrm{P} & =\text { Daya }(\text { watt }) \\
\mathrm{V} & =\text { Tegangan sumber }(\mathrm{V}) \\
\mathrm{I} & =\text { Arus }(\mathrm{A})
\end{array}
$$

Jadi untuk melakukan perhitungan daya output motor adalah sebagai berikut.

Diketahui :

$$
\begin{aligned}
\mathrm{V} & =12 \mathrm{~V} \\
\mathrm{I} & =2 \mathrm{~A} \\
\mathrm{P} & =\mathrm{V} \times \mathrm{I} \\
& =12 \mathrm{~V} \times 2 \mathrm{~A} \\
& =24 \mathrm{Watt}
\end{aligned}
$$

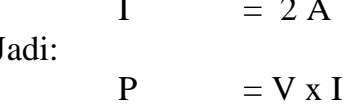

Maka diambil motor power window yang ada dipasaran yaitu motor listrik DC $12 \mathrm{~V} 2 \mathrm{~A}$ dengan daya 24 watt.

\section{IV.KESIMPULAN}

\section{A. Kesimpulan}

Dari hasil pengujian dan analisa pada Sistem Pemberian Pakan Ayam Otomatis Berbasis Loadcell yang telah dibuat, maka didapatkan kesimpulan, Berat pada loadcell melebihi kapasitas yaitu $1000 \mathrm{~g}$ maka secara otomatis motor servo akan mentup pintu pada bak dan pakan tidak akan keluar lagi. Motor power window akan berhenti menggerakan bak kembali ke posisi semula. Pada pengujian pengaplikasian motor power window ini menggunakan relay untuk membalik putaran motor power window pada bak pakan dari CW (clock wise) dan CCW (counter clock wise).

\section{B. Saran}

Berdasarkan pembuatan sistem pemberian pakan ayam otomatis yang penulis buat, masih terdapat kekurangan pada alat. Untuk itu penulis memberikan saran agar kedepannya alat ini dapat ditambahkan dengan memberikan air otomatis ketika pakan pada bak penampung hampir habis kepada pekerja.

\section{REFERENSI}

J. O. Panekenan, J. C. Loing, B. Rorimpandey, and P. O. V. Waleleng, "Analisis Keuntungan Usaha Beternak Ayam Di kecematan Sonder Kabupaten Minahasa," Ilmu Ilmu Peternak., vol. 32, no. 5, pp. 1-10, 2013.

[2] H. R. Tamba, E. Suprijatna, and U. Atmomarsono, "Pengaruh Frekuensi dan Periode Pemberian Pakan yang Berbeda terhadap Tingkah Laku Makan 
Burung Puyuh Petelur," J. Sain Peternak. Indones., vol. 14 , no. 1 , pp. 28-37, 2019.

[3] E. J. Manurung, "Performa Ayam Broiler Pada Frekuensi Dan Waktu Pemberian Pakan Yang Berbeda," pp. 1-43, 2011.

[4] B.A.B.II and T. Pustaka, "(Sumber: www.lapantech .com 'Load- 133'cell.2013),” pp. 4-28, 2013.

[5] Hestylesta, "Bab ii teori penunjang 2.1 umum," pp.
6-26, 2009.

[6] M. A. Kurniawan, "Aplikasi Accelerometer pada Penstabil Monopod Menggunakan Motor Servo," pp. 5-31, 2016. 